\title{
The Impact of External Instability and Socio-economic Infrastructure on the Productivity Dynamics of North Cyprus
}

\author{
Prof. Dr. Mustafa İsmihan (Eastern Mediterranean University, TR of Northern Cyprus) \\ Prof. Dr. Mustafa Besim (Eastern Mediterranean University, TR of Northern Cyprus) \\ Assoc. Prof. Dr. Kamil Sertoğlu (Eastern Mediterranean University, TR of Northern Cyprus)
}

\begin{abstract}
This study aims to explore the long-term productivity dynamics of the economy of the Turkish Republic of Northern Cyprus by using a simple Autoregressive Distributed Lag (ARDL) Model. More specifically, we aim to analyze the impact of macroeconomic instability and socio-economic infrastructure on total factor productivity over the 1977-2017 period. Additionally, this study develops a socio-economic infrastructure index by combining information from communication, energy, education and health indicators. The main result of this paper is that while total factor productivity is positively and significantly affected by the improvements in socio-economic infrastructure it is negatively affected from the external macroeconomic instability.
\end{abstract}

\section{Introduction}

Productivity growth is of central importance to economic growth and development in every economy. More than half a century ago, Solow (1957) developed a method for decomposing economic growth based on the contribution of the primary factors of production (capital and labor) and the total factor productivity (TFP). In its basic form, neo-classical model postulates that in the long run two critical factors determining growth are exogenously given; respective rates of technological progress and population growth. And, in the medium-term, accumulation of not only labour force which depends on the rate of population growth but also that of physical capital will play a critical role in determining the growth rate of the economy as explained by Solow (1957) and Froyen (1998). In short, for the quantity of output to grow, either the quantity of inputs must grow or productivity must improve, or both.

The literature on definition, measurement and explanation of sources of growth of TFP are extensive. Weil (2005) defines TFP or 'Solow residual' as the multiplication of efficiency and technology. Literally, the growth in TFP measures the improvement of productivity in production function where the improvement can come from various sources including better utilization of tangible and intangible capital (human and organizational) (Jeong and Townsend, 2007).

In this study, we specifically aim to investigate the impact of external macroeconomic instability on TFP. In order to be able to identify a more solid impact of external macroeconomic instability, we add socio-economic infrastructure (by combining communication, energy, education and health indicators) as control variable to our analysis given the critical role of knowledge indicators on TFP -à la endogenous growth models (see, e.g., Chen and Dahlman, 2004, Froyen, 1998). As for the case study, we take North Cyprus economy which is a micro size economy producing approximately 4 billion USD of GDP a year (Besim and Sertoğlu, 2015). The case of North Cyprus is unique as it has very high level of economic relations with Turkey and the channels for instability are diverse and critical. These are both through financial markets as well as products markets. The volume of trade between North Cyprus and Turkey represents more than 80 percent of total trade of North Cyprus (SPO, 2019). The legal tender in North Cyprus is Turkish Lira (TL) which makes the economy to be functioning in the Lirazone with Turkey. So, changes in the value of TL against major hard currencies directly affect the trade and prices in North Cyprus. Monetary policy change by Central Bank of Turkey also has implication on the money market in North Cyprus with different levels of interest rates and amounts of money in the money market. Furthermore, the two leading sectors of North Cyprus, one being tourism and the other higher education, are also generating most of their incomes from Turkey. The other channel that stands as a potential instability channel is the fiscal assistance of Turkey to North Cyprus, though have been declining in the recent years, it varies from 20-30 percent of the budget. This fiscal dependence of North Cyprus, at times when Turkey faces financial difficulties, jeopardizes the flow of capital that is budgeted for infrastructure investments as well as for financing the deficit in the recurrent budget. All these explained channels are potential vehicles for the transmission of the instability to North Cyprus economy.

From an economic view point, our main motivation is to understand to what extent macroeconomic stability in Turkey has significant impact on the TFP in North Cyprus. In this respect, in the following section we introduce our model and then provide and interpret the preliminary empirical results. 


\section{The Model and Empirical Results}

In this study we follow Musolesi (2011) and utilize a TFP framework to analyze the impact of macroeconomic instability and socio-economic infrastructure on total factor productivity. In doing so, the following TFP model is considered:

$$
\operatorname{Ln} A_{t}=\beta_{0}+\beta_{1} \operatorname{Ln} S_{t}+\beta_{2} \operatorname{Ln} I_{t}
$$

where $A_{t}=$ TFP (Solow Residual), $S_{t}=$ Socio-economic infrastructure; $I_{t}=$ external macroeconomic instability and $\mathrm{Ln}=$ natural logarithm. [It should be noted that Equation (1) is derived from $A_{t}=\beta_{0}{ }^{\prime} S_{t}^{\beta_{1}} I_{t}^{\beta_{2}}$ ]

Before we estimate the above TFP equation with the yearly time series data from 1977 to 2017 (The data sources and definitions are provided in the appendix.), it is essential to determine the time-series properties (i.e. the presence of a unit root) in each series. Table 1 presents the ADF test results. When we consider the levels of all the variables ( $\mathrm{Ln}$ A50, LnA35, Ln I and Ln S), the null hypothesis of a unit root is not rejected at the 5\% significance level. Furthermore, the null of a unit root for the first differences of the variables are rejected at the $1 \%$ significance level. Thus, all of these variables seem to contain a unit root at the $5 \%$ significance level. However, the results are not clear at the $10 \%$ significance level for all variables except $\mathrm{Ln} \mathrm{S}$.

\begin{tabular}{|l|c|c|c|}
\hline \multirow{2}{*}{ Variables } & \multicolumn{3}{|c|}{ ADF Tests } \\
\cline { 2 - 4 } & \multicolumn{2}{|c|}{ Level } & First Difference \\
\cline { 2 - 4 } & Without Trend & With Trend & Without Trend \\
\hline Ln A50 & $-1.6090(1)^{\mathrm{b}}[0.4686]^{\mathrm{c}}$ & $-3.4422(1)[0.0604]$ & $-4.6027(0)[0.0007]$ \\
\hline Ln A35 & $-1.1924(1)[0.6681]$ & $-3.3224(1)[0.0704]$ & $-4.4377(0)[0.00010]$ \\
\hline Ln S & $-1.0835(0)[0.7130]$ & $-1.6851(0)[0.7394]$ & $-6.2711(0)[0.0000]$ \\
\hline Ln I & $-2.6269(0)[0.0961]$ & $-6.1906(0)[0.0000]$ \\
\hline
\end{tabular}

Table 1. ADF Tests

The dynamic empirical relationship between socio-economic infrastructure, external instability and TFP can be analyzed by using cointegration approach. However, when we take into account the possibility of the mix of $\mathrm{I}(0)$ and I(1) variables, the above TFP model is estimated with the ARDL technique. The long-run estimation result is as follows (ARDL Bounds test confirms the existence of cointegration relation):

$$
\begin{gathered}
\operatorname{Ln} A 35_{t}=4.547+0.777 \operatorname{Ln} S_{t}-0.549 \operatorname{Ln} I_{t} \\
{[0.0000] \quad[0.0030]}
\end{gathered}
$$

Note: $p$-values are provided in square brackets.

This equation indicates that while total factor productivity is positively and significantly affected by the improvements in socio-economic infrastructure it is negatively affected from the external macroeconomic instability. All these results are consistent with a priori expectations mentioned in Section 1 (It should be also noted here that we obtained similar results with Ln A50 used as a dependent variable and when we consider the inflation rate of North Cyprus as an additional control variable).

\section{Conclusion}

Our preliminary results indicate that external macroeconomic instability has detrimental effects on TFP whereas improvements in socio-economic infrastructure improve productivity. This results which are in line with the work of İsmihan and Özcan (2009), implies that, macroeconomic instability in Turkey distorts the resource allocation by creating uncertainty and has a negative impact on the TFP in North Cyprus -through various channels. The results also show that North Cyprus economy is highly fragile given the permanent negative impact of external instability on TFP. 


\section{Appendix}

\section{Data Definitions and Sources}

A refers to the estimated TFP (Solow residual) with $\alpha$ set at 0.50 and $0.35\left[\mathrm{~A}=\mathrm{Y} /\left(\mathrm{K}^{\alpha} \cdot \mathrm{L}^{1-\alpha}\right)\right]$ (see, İsmihan and Metin-Ozcan, 2006).

Y (output) is measured by GDP (at 1977 prices).

$\mathbf{K}$ (physical capital stock) is calculated by perpetual inventory method as in Ismihan and Metin-Ozcan (2006). Gross fixed capital investment is used in calculation of $\mathrm{K}$.

$\mathbf{L}$ (labor input) is measured by employment data.

The Socio-economic Infrastructure Index (S) is developed by combining information from communication, energy, education and health indicators. This index is calculated by using human development index (HDI) methodology and it is a weighted average of the four sub-indices obtained from those four indicator by using the principal components analysis.

Macroeconomic Instability Index (I or INSW) is developed by İsmihan $(2009,2012)$ and used as a proxy for macroeconomic instability. This index is calculated by using human development index (HDI) methodology and it is based on four macroeconomic instability indicators; namely, public deficit to GDP ratio, inflation rate, change in the current account balance to GDP ratio and change in exchange rate. Note that the absolute values of the last three indicators are used. INSW is a weighted average of the four sub-indices obtained from these four variables and the respective weights are determined by using the principal components analysis. Source: İsmihan (2012).

All the data for the North Cyprus economy are obtained from State Planning Organization.

\section{References}

- Besim, M. and Sertoğlu, K., 2015. Kuzey Kıbrıs Türk Cumhuriyeti’nde İstikrarlı ve Sürdürülebilir Ekonomik Büyüme: Sektör Temelli Analiz ve Politika Önerileri [Stable and Sustainable Economic Growth in the Turkish Republic of Northern Cyprus: Sectoral Analysis and Policy Recommendations], Report, Eastern Mediterranean University. Famagusta, North Cyprus.

- Chen, D. H. C. and Dahlman C. J., 2004."Knowledge and Development: A Cross-Section Approach", World Bank Research Working Paper 3366.

- Froyen, R., 1998. Macroeconomics, Prentice-Hall, London.

- İsmihan, M. (2009). The Role of Politics and Instability in Macroeconomic Performance: Theory and Lessons from the Turkish Experience. VDM Verlag Dr. Muller, Saarbrucken, Germany.

- İsmihan, M. and Metin-Ozcan, K., 2006. "Türkiye Ekonomisinde Büyümenin Kaynakları, 1960-2004", İktisat İsletme ve Finans, 241, pp. 74-86.

- İsmihan, M., 2012. "The Political Economy of Productivity Collapses and Accelerations: The Turkish Experience, 1950-2010", in Proceedings of ICE-TEA (Türkiye Ekonomi Kurumu, Uluslararası Ekonomi Konferans1 2012), 1-3 November 2012, İzmir, Türkiye.

- Jeong, H. and Townsend, R.M., 2007. "Sources of TFP Growth: Occupational Choice and Financial Deepening", Economic Theory, 32, p. 179.

- Musolesi, A., 2011. "On Public Capital Hypothesis with Breaks", Economics Letters, 110, pp. 20-24.

- Solow, R., 1957. "Technical Change and the Aggregate Production Function", Review of Economics and Statistics, 39, pp. 312-20.

- SPO, 2019. Statistical Year Book, State Planning Organization, Prime Ministry, Nicosia, North Cyprus.

- Weil, D., 2005. Economic Growth. Addison Wesley, Boston. 